WIENER SLAVISTISCHES JAHRBUCH, Band 54/2008, 77-90

(C) 2008 by Österreichische Akademie der Wissenschaften, Wien

ANDREAS LEBEN

\title{
Bahtinovo pojmovanje avtobiografije in avtobiografsko v delu Lojzeta Kovačiča
}

Pričujoči prispevek je poskus analitične primerjave pojmovanja avtobiografije $\mathrm{v}$ zgodnjih delih Mihaila M. Bahtina in v prozi, esejih in intervjujih Lojzeta Kovačiča. Seveda je upravičeno vprašanje, ali je tozadevna primerjava med dognanji, ki jih je vplivni ruski mislec in teoretik pozneje bistveno dopolnil, in razmišljanji nemara najizrazitejšega slovenskega pisca avtobiografske proze sploh možna in kakšna spoznanja lahko pričakujemo. Nenazadnje je Bahtin po mnenju S. S. Averinceva napisal svoj nedokončani, ne v celoti ohranjeni spis Avtor i geroj v éstetičeskoj dejatel'nosti, ki nas tu posebej zanima, najbrž že v letih 1920-1924 (Bahtin 1979: 384), objavljen pa je bil šele leta 1979 v postumno izdanem zborniku Éstetika slovesnogo tvorčest$v a{ }^{1}$ Gre za delo, v katerem Bahtin, glede na poznejše spise, najobširnejše razpravlja o avtobiografiji, vsebuje pa tudi misli, ki že kažejo na njegove teorije kronotopa, dialoga in polifonije. Leta 1928 rojeni Kovačič v svojih zapisih in izjavah sicer navaja številne vplive na svoje delo in mišljenje, toda Bahtina nikjer ne omenja, čeprav segajo začetki recipiranja Bahtinovih del $\mathrm{v}$ jugoslovanskem prostoru že $\mathrm{v}$ trideseta, $\mathrm{v}$ ožjem slovenskem prostoru pa vsaj v sedemdeseta leta (Juvan 1997: 5-6). O kakem neposrednem vplivu Bahtina na Kovačiča torej ne kaže govoriti, in vendar nam Kovačičeve avtorefleksivne in avtotematske izjave ${ }^{2}$ pokažejo, da se je loteval podobnih vprašanj kot Bahtin, na primer kar zadeva pisateljevo ustvarjalno odgovornost, povezavo med življenjem in literaturo ali odnos avtorja in pripovedovalca do samega sebe, do drugega $\mathrm{v}$ sebi in do drugih. Zaradi časovne razdalje in načeloma različnega ustroja Bahtinovih filozofsko-znanstveno in Kovačičevih življenjsko-pisateljsko ute-

${ }^{1}$ Leta 1979 je revija Kunst und Literatur v 6. in 7. številki objavila del Bahtinovega spisa v nemškem prevodu, v srbskem prevodu je v celoti izšel leta 1991, v slovenskem pa leta 1999.

2 Naj bo omenjeno, da je bil Bahtin skeptičen do tozadevnih »avtorskih izpovedi«, češ da umetnik nima česa povedati o procesu svojega ustvarjanja, da je »ves v ustvarjenem izdel$\mathrm{ku} \ll$ in mu preostane le to, da opozori na svoje delo (Bahtin 1999: 14). 
meljenih razmišljanj se za podrobnejšo primerjavo med njimi ponuja predvsem kontrastivni pristop, ki nas obenem lahko opoziri na kontinuiteto in spremembe $\mathrm{v}$ estetskem vrednotenju avtobiografije in avtobiografskega pisanja $v 20$. stoletju.

V spisu Avtor in junak v estetski dejavnosti ${ }^{3}$ se Bahtin dotika vprašanja avtobiografije $\mathrm{v}$ sklopu analize avtorjevega razmerja do junaka in junaka do avtorja, tako da o zvrstnih in žanrskih vidikih ne razpravlja posebej in samo bežno ugotavlja, da je oblika biografije »znanstveno dovolj nenačelna« (Bahtin 1999: 227). Njegova izvajanja pa kažejo, da izhaja iz podobnega duhovnozgodovinskega pojmovanja avtobiografije kot Wilhelm Dilthey in Georg Misch, saj predpostavljajo obstoj samozavestnega, sebe zavedajočega se subjekta in sledijo zahtevi, da naj bo avtobiografija vrednostno opredeljen in celosten prikaz življenja. ${ }^{4} \mathrm{~V}$ skladu s tem gleda Bahtin na besedno umetniško ustvarjanje tudi s celostnega humanističnega vidika, v katerega jedru vidi znanost, umetnost in življenje, in samo posamezniku pripisuje možnost, da tem trem področjem človeške kulture pridobi enovitost. Samo posameznik jih lahko združi v celoto, to pa samo, če tudi sprejme celovitost odgovornosti in krivde tako $\mathrm{v}$ umetnosti kot $\mathrm{v}$ življenju, ki da nista eno, morata pa postati enotna $\mathrm{v}$ posamezniku, v enovitosti njegove odgovornosti. ${ }^{5}$ Umetniško delo mu zato tudi pomeni »živ umetniški dogodek enotnega in edinstvenega dogodka bivanja« (209).

Če te misli prenesemo na spis o avtorju in junaku, je avtor tista instanca, ki je v celoti odgovorna za junaka, ki intonira vsako njegovo nadrobnost. Bahtin zahteva od avtorja umetniškega dela, da se mora odzvati na junakova ravnanja $\mathrm{z}$ enovito reakcijo na junakovo celost. Ta nastaja iz enovitega avtorjevega vrednostnega razmerja do junaka, ki ga mora avtor razviti, da je lahko estetsko dejaven (12-13). Z drugimi besedami: »Avtor je nosilec intenzivno aktivne enovitosti sklenjene celote, celostnega junaka in celostnega dela, in presega sleherno junakovo sestavino« (20).

Po Bahtinu znotraj junaka samega taka celost načeloma ne more biti dana in prehaja na junaka samo kot darilo iz stvariteljske zavesti avtorja, ki zaobjema in dokončuje zavest junaka in njegov svet. Junak sam ne more živeti v celosti in dokončanos-

${ }^{3}$ Izvirni naslov Avtor i geroj v éstetičeskoj dejatel'nosti ni Bahtinov, ker tako naslov kot začetek spisa nista ohranjena, temveč ga je določil urednik S. G. Bočarov ob prvi objavi spisa v Bahtinovem zborniku Estetika slovesnogo tvorčestva (1979).

4 Dilthey je avtobiografijo označil kot najvišjo in najbolj instruktivno obliko, v kateri človeku stopa naproti razumevanje življenja, oziroma kot do pisateljskega izraza privedeno človekovo samoovedenje poteka njegovega lastnega življenja (Dilthey 1993: 246, 247; glej tudi Dilthey 2002: 218, 219). Podobno je njegov učenec Georg Misch poudaril avtobiografovo sposobnost, da svojim doživetjem pripiše pomen in svoje življenje razume kot enovito celoto, zgodovino avtobiografije zahodnega sveta pa je interpretiral tudi kot zgodovino človekovega samozavedanja (Misch 1949: 10, 11). Osnovna misel teh duhovnozgodovinskih pogledov je, da je človekova identiteta predstavljena $\mathrm{v}$ besedilu in da je življenje človeka predhodno jezikovnemu izrazu. Jezik je pojmovan kot izrazni medij, ki se ga poslužuje sebe zavedajoči se subjekt.

5 Te misli je Bahtin izrazil v članku Umetnost in odgovornost, objavljenem leta 1919 (Bahtin 1999: 7-8) 
ti, kot mora biti tudi človek, da bi živel, »nedokončan, odprt zase [...] v vseh bistvenih trenutkih življenja, njegova prava vrednost mora biti pred njim, v prihodnosti« (21). Temeljni pogoj za estetsko produktivno razmerje avtorja do junaka je zato $z u$ najbivanje (rus. vnenachodimost') avtorja v odnosu do vseh junakovih sestavin prostorskih, časovnih, vrednostnih in pomenskih:

Samo zunajbivanje avtorja omogoča, da zberemo vsega junaka, ki je znotraj samega sebe raztresen in razmetan $\mathrm{v}$ zadanem svetu spoznavanja in $\mathrm{v}$ odprtem dogodku etičnega ravnanja. (23)

Položaj zunajbivanja zahteva Bahtin tudi tedaj, kadar je junak avtobiografski. Avtor se mora postaviti zunaj sebe, da lahko dopolni samega sebe do celote $z$ vrednotami, ki presegajo in dokončujejo življenje v njem samem. »Avtor mora postati drugi v razmerju do samega sebe, pogledati mora nase $\mathrm{z}$ očmi drugega« (24). Bahtin ugotavlja, da človek to počenja tudi v vsakdanjem življenju, da lovi odseve svojega življenja v zavesti drugih. Tudi če bi se človeku posrečilo zajeti celoto svoje zavesti, dokončane $\mathrm{v}$ drugem, pa Bahtin ne verjame, da bi mogla ta celota človeka obvladati in ga dejansko dokončati za njega samega, ker zavest človeka »sama sebi nikdar ne bo izrekla zaključne besede« (25). Prav to pa Bahtin predpostavlja za estetsko samoobjektivacijo avtorja-človeka v junaka:

[...] celota junaka mora ostati zunaj avtorja-drugega poslednja celota. Avtorja kot avtorja je treba v celoti ločiti od avtorja-junaka, ki ga je treba opredeliti celostno, [...] avtor mora v sebi-junaku videti drugega kot dokončno celoto. Estetska samoobjektivacija avtorja-človeka $\mathrm{v}$ junaka mora podstaviti pod junakovo zavest transgredientno ozadje, ozadje, ki to zavest presega, avtor mora poiskati oporno točko zunaj junaka, da bi postal estetsko zaključen pojav - junak. $(25-26)^{6}$

Če avtor izgubi to vrednostno točko zunajbivanja, potem so po Bahtinu mogoči trije splošni tipični primeri avtorjevega odnosa do junaka (26-30):

1. Junak obvlada avtorja (avtor vidi sebe in svet $\mathrm{z}$ očmi junaka; ni enovite avtorjeve podobe, ta je raztresena ali pa je pogojna krinka).

2. Avtor obvlada junaka (vanj vnaša momente, ki ga zaključujejo, razmerje avtorja do junaka postaja deloma odnos junaka do samega sebe; če je junak avtobiografski, si prisvoji zaključujoči avtorski refleks, njegovo totalno oblikujočo reakcijo, toda zaključeno celotnost doživlja kot omejitev in jo premaga; tak (romantični) junak je za avtorja neskončen, vedno znova se preraja in terja vedno nove zaključujoče oblike).

${ }^{6}$ Ozadje teh razmišljanj je Bahtinovo zavračanje zgolj faktografskega pristopa glede junakove in avtorjeve biografije in njunih svetovnih nazorov, ki je po njegovi oceni popolnoma prevladoval $v$ ruski literarni zgodovini in slonel na mešanju avtorja-ustvarjalca (dejavnika v delu) in avtorja-človeka (dejavnika v etičnem, družbenem dogodku življenja) in na nerazumevanju ustvarjalnega načela avtorjevega razmerja do junaka (Bahtin 1999: 1819). 
3. Junak je sam svoj avtor (svoje lastno življenje osmišlja estetsko, kot da igra vlogo, je samozadovoljen in prepričano zaključen; možna je ironizacija, a tudi heroizacija junaka).

Vse tri primere razume Bahtin kot odstopanje od ideala zunajbivanja avtorja glede junaka, ki je prvi pogoj za estetski dogodek. Ta se namreč ne more zgoditi, če je prisoten en sam udeleženec, kar Bahtin utemeljuje s tem, da absolutna zavest ne more biti estetizirana, ker ob sebi nima ničesar, kar bi jo presegalo, kar bi bivalo zunaj nje in jo od zunaj omejevalo. Estetski dogodek je zato mogoč samo pri dveh udeležencih in predpostavlja dvoje zavesti, ki se ne ujemata. Kadar se junak in avtor ujemata ali se znajdeta hkrati drug ob drugem pred obličjem iste vrednote ali drug zoper drugega kot sovražnika, se konča estetski dogodek in začenja se etični dogodek, kot ga je najti v pamfletih, manifestih, obtožnicah, hvalnicah, izrazih hvaležnosti, sramotenju, samoobračunih in spovedih. Kadar junaka sploh ni (v traktatu, razpravi, predavanju), gre za spoznavni dogodek; kjer obstaja druga zavest kot vseobsegajoča zavest Boga, pa gre za religiozni dogodek kot v molitvi, kultu in ritualu (30-31).

Iz te tipologije dogodkov je razvidno, da edino pozicija drugega omogoča estetski dogodek in estetsko dejavnost. Ravno v avtobiografijah pa ta pozicija ni zmeraj dana, prej nasprotno, saj velja ujemanje avtorjeve in junakove zavesti, istovetnost avtorja in junaka $\mathrm{v}$ konvencionalnih predstavah celo za konstitutivno prvino avtobiografije.

Vživetje avtorjevega jaza v drugega ali v druge je po Bahtinu potrebno tudi zato, da dobi lastno življenje, opisano od rojstva in celo po anticipirani smrti, svojo vrednost, kajti vrednosti, ki pripadajo »eksistenci kakovostno opredeljene osebnosti«, ima v lasti samo drugi (122). Življenje v svojem lastnem kontekstu »nima nobene estetske teže glede na svojo zgodbo in potek te zgodbe«, vrednost in smisel življenja sta na popolnoma drugi vrednostni ravni. V odnosu do samega sebe (jaz-za-sebe) zato ne more biti vzpostavljen vrednostni junak, ni moč doživeti niti časa, ki bi bil emocionalno konsolidiran, niti prostora. Že opredeljeni čas in prostor jaza sta čas in prostor avtorja, ne pa junaka (123). Življenje, pri čemer Bahtinu ne gre za dostopnost vsega življenja, je v tem smislu zgolj gradivo, ki ga lahko estetsko oblikuje samo drugi oziroma avtor, ki se je vživel v drugega. Pri tem Bahtinu pomeni spomin o zaključenem življenju drugega »zlati ključ estetskega dokončanja osebnosti«, kajti »spomin je pristop z vidika vrednostne dokončnosti«, tu se začenja »konsolidacija in dokončanje osebnosti v estetsko pomembni podobi« (124). Znotraj teh mej je nato mogoče popolnoma drugače razporediti in oblikovati življenje, ker je »osvobojeno krempljev predhodnega, prihodnjega cilja in smisla, postane emocionalno izmerljivo, muzikalno izrazno, zadostno samo sebi, v svoji popolni disponibilnosti« (125).

Kot je razvidno že iz tipologije dogodka, povezuje Bahtin estetsko z umetnostjo, etično pa z življenjem. Misli in postopki znotraj jaza imajo zanj samo spoznavno in etično vrednostno veljavo, ne pa estetske. Življenje je opredeljeno s smislom, medtem ko je umetniški interes »interes zunaj smisla, interes za načelno zaključeno živ- 
ljenje« (129). Samo ta interes omogoča estetsko videnje sveta, ki ga je treba razumeti kot svet drugih in v katerem se je treba počutiti kot doma, če naj pride do prehoda od izpovedi k objektivnemu estetskemu opazovanju, od iskanja smisla »k lepi danosti sveta« (128-129).

V vlogi drugega, v nujni zamejitvi in dokončanosti življenja s pozicije drugega, je tudi utemeljeno, zakaj Bahtin na ravni naravnanosti zavesti ne vidi ostre načelne ločnice med avtobiografijo in biografijo in ugotavlja, da niti v biografiji niti v avtobiografiji odnos do samega sebe ni organizirajoči, konstitutivni dejavnik oblike (170). ${ }^{7}$ Pojma biografija in avtobiografija (življenjepis) $\mathrm{mu} v$ tem sklopu pomenita najbližjo presegajočo obliko, v kateri je moč objektivirati življenje na umetniški način. Oblika (avto)biografije ga pri tem zanima predvsem z vidika možne skladnosti junaka in avtorja v njej oziroma $\mathrm{z}$ vidika posebnega značaja avtorja in njegovega odnosa do junaka. Vendar Bahtin poudarja, da je skladnost junaka in avtorja contradictio in adiecto, ker je avtor dejavnik umetniške celosti, ki se v tej celosti ne more skladati z junakom, drugim dejavnikom te celosti. ${ }^{8}$ Osebnostno ujemanje v življenju osebe, o kateri je govor, $\mathrm{z}$ osebo, ki govori, da ne odpravlja razlike med tema dejavnikoma znotraj umetniške celote (170). ${ }^{9}$ Pri tem Bahtina zanimajo samo takšne oblike avtobiografije, ki realizirajo umetniško-biografske vrednote, ne pa kakršne koli objektivne, praktične ali znanstveno-zgodovinske smotre, nas pa mora zanimati, za kakšne umetniško-biografske vrednote gre in kako jih Bahtin določa glede na umetniško celoto. Njegove ugotovitve lahko povzamemo takole:

1. Biografska umetniška vrednota je med vsemi vrednotami najmanj presegajoča v odnosu do samozavedanja. Avtor v biografiji je najbližji njenemu junaku, avtor in junak kakor da lahko zamenjata mesti, zato je tudi možno osebnostno ujemanje junaka in avtorja zunaj umetniške celote. Biografska vrednota tako lahko organizira pripoved o življenju drugega, doživljanje življenja samega in pripoved o svojem življenju (171). Tudi junak in pripovedovalec lahko zamenjata mesti, če je vrednostna pozicija drugega avtoritetna in drugi lahko pripoveduje o življenju junaka $\mathrm{v}$ popolnem soglasju $\mathrm{z}$ njim, kot junak, ki je vase sprejel vrednostnega drugega, v soglasju z drugim lahko začenja pripovedovati o drugem, s katerim živi v skupnem vrednostnem življenju družine, nacije, človeštva (172-173).

${ }^{7}$ V članku o antični biografiji in avtobiografiji iz let 1937/38 Bahtin utemeljuje misel, da ni načelnih razlik med avtobiografskim in biografskim glediščem, s popolno pozunanjenostjo notranjosti tedanjega človeka, z njegovo javno celovitostjo (Bahtin 1982: 260).

${ }^{8} \mathrm{Za}$ Bahtina sta avtor in junak pravzaprav dva druga, dve zavesti, samo da med njima ni načelne nasprotipostavljenosti, ker sta $\mathrm{v}$ istem vrednostnem avtoritetnem svetu drugih (Bahtin 1999: 183).

9 V svojih poznejših razmišljanjih o obliki časa in kronotopa v romanu Bahtin še jasneje poudarja, da ostaja avtor-ustvarjalec, četudi je ustvaril avtobiografijo ali najpristnejšo izpoved, zunaj prikazanega sveta, ker je zunaj časa in prostora, v katerem se je dogodek, ki ga pripoveduje ali opisuje, pripetil (Bahtin 1982: 368). 
2. Biografska oblika je najbolj realistična, ker je v njej najmanj izolirajočih in dokončujočih dejavnikov. Aktivnost avtorja je najmanj preoblikujoča, avtor načelno najmanj uporablja svoj vrednostni položaj zunaj junaka, omeji se skoraj samo na zunanjo, prostorsko in časovno zunajbivanje, ni jasnih mej značaja, razvidne izolacije, zaključenosti in napete fabule (171).

3. Biografske vrednote so skupne življenju in umetnosti, lahko določajo praktična dejanja kot njihov smoter; to so oblika in vrednote estetike življenja (171).

4. Vrednostna biografska enotnost je možna samo, če pripovedujejo tudi drugi; iz ust drugih junakov »svojega« življenja »jaz« izve velik del svoje biografije (rojstvo, izvor, dogodki v zgodnjem otroštvu), brez pripovedi drugih bi življenje jaza ostalo razbito (173).

5. Fragmenti življenja (fragmenti z vidika biografske celosti), ki jih jaz doživi od znotraj, dobijo lahko samo notranjo enotnost $v$ odnosu do samega sebe, t. j. enotnost spovedi kot obračuna s samim seboj, ne pa biografije. Notranje načelo enotnosti ni primerno za biografsko pripoved, ker je za biografijo potrebna vrednostna pozicija drugega (173-174).

Da je biografska umetniška vrednota med vsemi vrednotami najmanj presegajoča v odnosu do samozavedanja, da je biografska oblika najbolj realistična, najmanj izolirajoča in dokončujoča in da so biografske vrednote skupne življenju in umetnosti so poglavitni razlogi za Bahtinovo relativiranje estetske in s tem umetniške vrednosti biografij in avtobiografij. To je logična posledica njegove zahteve po dokončanosti junakovega življenja s pozicije drugega in njegovega načelnega razumevanja (avto)biografije kot pozunanjenega, objektiviranega življenja. ${ }^{10}$ Zato tudi meni, da samo »tesna, organska vrednostna vključenost v svet drugih ustvarja avtoritetno in produktivno biografsko samoobjektivacijo življenja« (174). Ta svet drugih pa mora biti sprejet pozitivno, saj vidi Bahtin temelj trdne oporne točke zunajbivanja v ljubečem svetu drugih, od katerih se »jaz« ne ločuje in kateremu se ne postavlja nasproti.

Vse doslejšnje opredelitve potiskajo avtobiografijo in njene umetniško-biografske vrednote na mejo med umetnostjo in življenjem, med literarnim in neliterarnim. ${ }^{11}$ Bahtin o odnosu junaka do avtorja $v$ biografiji tudi ugotavlja, da je tak avtor naiven, $v$ sorodstvu z junakom, da ni popoln umetnik, ker njegove vrednote niso povsem estetske, hkrati pa tudi junak ni popoln etični subjekt, ker so njegove vodilne vrednote estetske (182-183). Tako pojmovan svet (avto)biografije ni dokončan, ni izločen $» s$ krepko začrtanimi in načelnimi mejami iz enotnega in edinstvenega dogodka bivanja«. Zato Bahtin biografijo tudi nima za ustvarjeno delo, pač pa za »es-

${ }^{10}$ Načelna pozunanjenost notranjosti človeka je tudi osnova Bahtinovih razmišljanj o antični avtobiografiji, ki da ni poznala ponotranjenosti človeka, ker naj bi se na agori »odkrivalo in videlo celotno življenje državljana« (Bahtin 1982: 260).

11 Takšen vmesni položaj pripisuje avtobiografiji tudi velik del slovenske literarne vede (glej Leben 2007: 94). 
tetizirano, organsko in naivno dejanje v načeloma odprtem, vendar organsko samozadostnem bližnjem vrednostno avtoritetnem svetu« (184).

Tako opredeljena (avto)biografija se pokaže v drugačni luči, če Bahtinova razmišljanja beremo hkrati kot kritiko določene prakse $\mathrm{v}$ avtobiografskem pisanju. To se zdi upravičeno $\mathrm{z}$ ozirom na njegovo ugotovitev, da je biografija namenjena »razumevajočemu, sorodno dojemajočemu bralcu, ki pripada svetu drugosti«, medtem ko jo »kritični bralec« sprejema »do neke mere kot napol neobdelano gradivo za dokončno umetniško oblikovanje« (185). Šele na koncu poglavlja o avtobiografiji Bahtin omenja možnost, da avtor vseeno lahko postane »popoln umetnik« in sicer tam, kjer »ni več naiven in povsem zakoreninjen v svetu drugosti, kjer je pretrgana sorodnost med junakom in avtorjem, kjer je avtor skeptičen do junakovega življenja«;

[...] tak avtor bo vrednotam junakovega življenja vedno stavil nasproti transgredientne, junakovo življenje presegajoče vrednote zaključenosti, to življenje bo zaključeval z načeloma drugačnega vidika, kot je tisto, ki ga je junak doživljal znotraj sebe. V takšni biografiji si bo vsaka vrstica, vsaka poteza pripovedovalca prizadevala uporabiti načelni presežek videnja, ker junak potrebuje transgredientno, t. j. sebe presegajoče opravičilo, v njej bosta avtorjev vidik in njegova aktivnost resnično zaobjemala in obravnavala prav načelne meje junaka glede na smisel tam, kjer je junakovo življenje obrnjeno navzven; tako bo med junakom in avtorjem začrtana načelna meja. (185)

Tako avtobiografija vendarle lahko izpolnjuje pogoje estetske dejavnosti in je lahko delo estetsko produktivnega avtorja. Sicer Bahtin v svojem spisu razpravlja tudi o primerih, ko junak ni zaključen, ko ni enovite podobe avtorja in vrednostna pozicija drugega slabi, ker junak obvlada avtorja (27-28), na drugem mestu osvetljuje celo krizo avtorstva, ko ni več mogoče biti umetnik, ko prihaja do preseganja umetnosti same, ko delovanje in ustvarjenje poteka neposredno $v$ enotnem dogodku bivanja s človekom kot edinstvenim udeležencem, ali ko se avtorju odreka pravica biti zunaj življenja in ga zaključevati, tako da življenje postaja razumljivo in pomebno kot dogodek samo od znotraj, v vrednostnih kategorijah jaz-za-sebe (222-223), ${ }^{12}$ toda Bahtin vrednostno vsekakor vztraja pri estetiki zunajbivanja in zaključenosti in $\mathrm{v}$ tem je tudi osnovna razlika med Bahtinovimi razmišljanji in pogledi Lojzeta Kovačiča.

O življenju, literaturi in svojem avtobiografskem pisanju je Kovačič obširno razpravljal v eseju Delavnica. Šola pisanja, objavljenem leta 1974 v prozni zbirki Preseljevanja. V spremnem besedilu k samostojni knjižni izdaji Delavnice leta $1997^{13}$ Kovačič razlaga, da je bil esej sprva lov za spoznanjem, za svojo bitjo, a da je ostal praznih rok, »ker spoznanje in vse drugo, kar se človeku zdi, da mu samoumevno pripada, kot mu pripada telo, teče pred njim že tri leta pred njegovim rojstvom«. V

12 Aleksander Skaza ugotavlja začetke krhanja veljavnosti estetike zaključenosti prav v zvezi z Bahtinovimi razmišljanji o krizi avtorstva, predvsem v delih F. M. Dostojevskega in A. Belega (Bahtin 1999: 365).

13 V pričujočem članku navajam iz ponatisa eseja iz leta 1997. 
skromnejši varianti je nato poskusil »povezati moralno-obrtni vidik pisanja z življenjem v atraktiven umetniški podvig«, z namenom, da bi ob genezi svojih del razkril,

[...] kako razbitost življenja določenega človeka vpliva na formo njegovega izražanja in v kakšnem sorazmerju živita med seboj realni čas, zmeraj pretesen za dogodek, in njegovi vzporedni tokovi (nelegalni, iracionalni, skrivnostni, tihotapski), ki človeka šele vpenjajo v središče dogajanja. (Kovačič 1997: 9-10)

Ta razbitost in fragmentarnost zaznamuje tako Kovačiča človeka in njegovo biografijo kot Kovačiča avtorja in pripovedovalca. Pri starih piscih sicer občuduje popolnost $\mathrm{v}$ formi in nravstvenost, iz katerih po njegovem šele nastaja umetnost, edini »obraz«, ki ga današnji ustvarjalec lahko s poštenostjo nosi, pa mu je v resnici fragment:

Fragment, osnutek ali skica - ta ima vedno samo smer, nikoli pa ne konca. Fragment je izraz sveta, ki se ne zapira ali se ne more več zapreti. Fragment mi je od nekdaj pomenil zmeraj nekaj takega kot moj strah pred formalno popolnostjo, ki želi venomer prehitevati duhovno, pomenil mi je nezaupnico za vse dokončno, kar me vseskozi oklepa, da bi dosegel svojo lastno izpolnitev. [...] Akropola v ruševinah je simbol otožja za nekdanjo celoto, a fragment je nasprotno obljuba za celoto in popolnost, ki naj bi nekoč, v prihodnosti, nastopila, katere pa nikoli ne bomo osvojili, vse dotlej, dokler ne bomo dobili odgovora na vsa naša vprašanja. (Kovačič 1997: 27)

Formalna in duhovna popolnost $\mathrm{v}$ literaturi sta potemtakem nedosegljivi, možna je kvečjemu popolnost $\mathrm{v}$ fragmentu, ki ima za Kovačiča tako daljnosežne spoznavne in ustvarjalne razsežnosti, ker literaturo dosledno povezuje z življenjem, ali z Bahtinom povedano, ker izhaja iz etičnega dogodka življenja in ostaja zavezan estetiki življenja, in prav na tej ravni je tudi največ podobnosti med njegovimi in Bahtinovimi razmišljanji. Kovačičev junak je znotraj samega sebe »raztresen in razmetan v zadanem svetu spoznavanja in odprtem dogodku etičnega ravnanja «, kot to Bahtin predvideva za junaka, ki ni zaključen. Ampak Kovačičev junak ostaja odprt in nedokončan, avtor ne išče rešitve v preseganju zavesti, ne išče zaključujoče vrednostne pozicije zunaj sebe, temveč poskuša ujeti čim več tistega, kar je realno ali vsaj potencialno $\mathrm{v}$ in ob junaku, kar je prisotno, a nerazkrito. Tako se Kovačičev avtobiografski junak dodobra ujema $\mathrm{z}$ Bahtinovo opredelitvijo človeka, ki mora biti nedokončan, odprt zase in v prihodnost, da lahko živi.

Za Bahtina je estetika življenja del biografskih vrednot, ki so skupne življenju in umetnosti, estetiko življenja pa je treba preseči s postopki estetske dejavnosti, ker v življenju samem in v notranjem življenju junaka ni mogoče doseči zahtevane celosti in dokončanosti umetniške celote. ${ }^{14}$ Drugače je pri Kovačiču, ki mu je estetika živ-

${ }^{14} \mathrm{~V}$ spisu o avtorju in junaku Bahtin obravnava vprašanje celosti $\mathrm{z}$ vidika pogojev estetske dejavnosti, v knjigah Problemi ustvarjanja Dostojevskega (1929) in Problemi poetike Dostojevskega (1963) pa svoj pogled na zaključenost junaka s teorijami dialoga in polifonega romana bistveno dopolni oziroma revidira. Junakova odprtost mu postane pogoj za dialoško pozicijo junaka $\mathrm{v}$ polifonem romanu, medtem ko zaključenost junaka povezuje z monološkim pripovednim načinom. Resnično življenje človeka se mu zdi dostopno samo prek dialoga, kadar življenje samo odgovarja in se svobodno odpira (Bahtin 1985: 58, 67). 
ljenja tudi vzorec in merilo za umetniško ustvarjanje. O tekstu govori kot organizmu (Kovačič 1993: 149), zato tudi meni, da v literaturi ni vse, da obstaja samo literatura odlomkov, kot je življenje sestavljeno samo iz drobcev (Komelj-Snoj 1997: 220). Po njegovem »se literatura nikoli ne sme sramovati pred življenjem« (Kovačič 1999: 31 ) in bi se morala vrniti tja, kjer je že bila: k pismu, dnevniku, izpovedi $(31,133){ }^{15}$ Kovačič govori tudi o »življenjskem slogu literature« v smislu pisanja iz notranje svobode (121-122), v knjigi Prah, v kateri je morda najnazorneje uresničil svoj način fragmentarnega pisanja, pa zavrača Rousseaujev izrek, »[v]zemite človeka stran in vse je dobro« in mu odgovarja: »Ne. Vzemite človeka stran in vse je nič« (Kovačič 1988: 35).

Tudi Kovačič vidi v življenju snov, ki jo mora avtor šele obdelati, ${ }^{16}$ vendar tega ne počne v smislu Bahtinove estetike, temveč na osnovi nezaključenosti in odprtosti, tako da se vedno spet lahko loteva istih dogodkov iz svojega življenja, tudi sanj, da bi jim prišel do dna ali jih vsaj osvetlil s čim več vidikov. To mu tudi omogoča, da iz odlomkov že objavljenih besedil sestavi novo knjigo, ${ }^{17}$ da iz različnih neuporabljenih zapisov oblikuje novo tekstovno enoto ${ }^{18}$ ali da na osnovi neobjavljenega gradiva napiše protiknjigo prejšnji, ker ga navdaja hotenje, »izčrpati na papirju vse svoje življenje do zadnje možnosti, do molka« (Komelj-Snoj 1997: 201).

Po Bahtinu je za biografijo potrebna vrednostna pozicija avtorja (drugega) tudi kot organizirajoči dejavnik oblike, ker imajo fragmenti življenja, ki jih jaz doživi od znotraj v odnosu do samega sebe, lahko samo notranjo enotnost. Pri Kovačiču je fragmentarnost temeljni princip, ki prežema vso notranjo in zunanjo strukturo njegovega pisanja vse tja do interpunkcije, tako da je tu odnos do samega sebe, drugače kot pri Bahtinu, morda celo najpomembnejši konstitutivni dejavnik oblike. Fragmentarnost zadeva tudi Kovačičev pogled na človeka kot subjekta, saj mu fragmentarnost ne pomeni samo »izraz sveta, ki se ne zapira več«, temveč tudi »izraz dvoma, da je bil človek v svoji zgodovini sploh kdaj celovita osebnost, ki se je lahko poistila sama s seboj in s kozmosom«, od sebe zato zahteva predvsem, da mora o stvari, opisani v fragmentu, biti povedano vse (Komelj-Snoj 1997: 220-221). Njegovo pisanje zato tudi ne sodi v območje avtobiografije v konvencionalnem pomenu, temveč vsebuje prijeme, ki spodnašajo mejo med avtobiografijo in modernim romanom (Koron 1991: 70-71).

Ta koncepcija junaka se seveda še bolj ujema z razmerjem med avtorjem in junakom pri Kovačiču, ki je svoje pisanje označil tudi dialog avtorja s samim seboj (Kovačič 1997: 187).

15 Glej tudi knjigo Pet fragmentov (Kovačič 1981: 288).

16 Kovačič primerja delo pisatelja $z$ delom svojega očeta krznarja, ki je v svoji delavnici iz kož različnih divjadi, iz žive snovi, izdeloval oblačila; podobno naj bi tudi pisatelj iz žive snovi, podtalno, prek vsebine transformiral simbole in like (Kovačič 1997: 15).

17 Glej knjige Preseljevanja (1974), Sporočila iz sna in budnosti (1987) in Tri ljubezni (2004).

18 Glej zbirko Prah (1988). 
Kovačič v svojih pisateljskih, estetskih in bivanjskih pogledih dosledno izhaja iz življenja, kar po svoje velja tudi za Bahtina, ki pa estetsko dejavnost avtorja in junaka vidi v preseganju danosti življenja. Da med njima dejansko obstaja neka globlja duhovna povezanost, nam pojasni pogled na celotno Bahtinovo »intelektualno dejavnost «. Sam je namreč o sebi zapisal, da v svojem delu združuje enotnost nastajajoče ideje, kar pogojuje določene notranje in zunanje nesklenjenosti mnogih njegovih misli, ker je nagnjen do mnoštva vidikov. ${ }^{19}$ Podobnost s Kovačičevimi pogledi na literaturo in življenje je očitna, kakor tudi njemu nikakor ni tuj Bahtinov estetski humanizem, ki temelji na predstavi o odgovornosti posameznika $\mathrm{v}$ umetnosti in $\mathrm{v}$ življenju, pri čemer odgovornost vključuje tudi sprejemanje krivde. Kovačič izraža takšno odgovornost že $\mathrm{s}$ tem, da $\mathrm{v}$ številnih avtorefleksijah razlaga tako vsebinsko kot formalno in moralno plat svojega pisanja in življenja. Ko na koncu Prišlekov govori o tem, da bo kaznovan za vse, kar je zamolčal, za vsako odkritosrčnost pa izplačan (Kovačič 1985: 392), in v drugih knjigah priznava krivdo, se izpoveduje in sramuje, je Kovačič dosleden tudi $\mathrm{v}$ tem, da mu ne gre za odgovornost pred svetom ali drugimi, temveč pred samim seboj, tako da za sebe tudi izključuje zmanjševanje krivde »s pokoro ali dobrimi deli« (Kovačič 1993: 205).

Življenje in literatura sta lahko povsem enakovredni in neločljivi kategoriji, kar Kovačič ponazarja z vidika spomina, spomina na življenje in literaturo, kajti v obeh primerih

[...] ostane samo neka vizualna podoba, glas, luč, metafora, duh kakšne sobe, zid, drevo itd. Tukaj se umetnost in življenje, učinek prikaza in prakse, ki ne moreta v celem ostati in pretrajati s človekom, enakopravno znajdeta skupaj iz oči v oči in se po intenziteti svojih moči izenačita in se skoraj združita. To je veliko za umetnost, več od nje ne smemo pričakovati, ker tudi več dati ne more. (Kovačič 1997: 36)

V nekem pogovoru pa se glede vezi med življenjem in literaturo izrazi še takole:

Če [...] meni kdo reče: literatura ali življenje - je malo nerodno, ker je literatura tako prepletena z življenjem. Jaz sem naselil toliko življenja v literaturo, da v bistvu ne vem, kaj bi dal - ali bi dal okno (to je življenje) ali zrcalo - ne morem se odločiti. In ker sem pisal zgodbe samo o sebi, sem čutil, da si ne morem izmišljevati njihove resničnosti. Jaz sedim v zgodbi svojega življenja, v fabuli svojega življenja - zdajle seveda bolj na priklopnem sedežu, bolj blizu izhoda. Zdaj ko je vse za mano, nekako vem, da sem imel prav, ker življenje prinese take napete zgodbe, strese, sanjarije, zbudi tisoč jazov, ki so v tebi. (Zor-Simoniti 2000: 52)

$\mathrm{Z}$ ozirom na ta razmišljanja in na zdaleč največji del Kovačičeve proze bi lahko rekli, da se pripovedovalec isti $\mathrm{z}$ realnim pisateljem, da s tem odpravlja pripovedno iluzijo, se "počloveči« in popolnoma postavi v vsakdanjost (Dolgan 2004: 164165), hkrati pa ne moremo govoriti o dejanski istovetnosti med realnim človekom, človekom umetnikom, pripovedovalcem in junakom. Kovačič na primer načelno razlikuje med notranjim procesom snovanja, ki se dogaja $\mathrm{v}$ njem, in procesom zapisovanja, ki poteka zunaj njega (Kovačič 1988: 111). Razlikuje, kdaj se »podvoji« v

${ }^{19}$ Povzemam po Aleksandru Skazi, v: Bahtin 1999: 355-356. 
junaka in govori o nekom drugem (Kovačič 1985: 391), kdaj prehaja iz prvoosebnega $v$ tretjeosebno pripovedovanje, ${ }^{20}$ kdaj opazuje samega sebe kot nekoga, ki mu je »do kraja nedostopen« (Kovačič 1993: 10).

Kovačičev odnos do junaka je mnogoplasten in neenoten, včasih ga gleda od daleč, včasih je tik ob njem, včasih prehaja vanj, največkrat pa njegov avtobiografski junak ni »pravi« junak, ker ga želi ohraniti nezaključenega. Tako v Delavnici omenja, kako je moral biti pazljiv, da v knjigi Deček in smrt (1972) »ne bi napravil iz sebe junaka, kar se tako rado zgodi v avtobiografijah « (Kovačič 1997: 122). Tipološko gledano pa gre vsekakor za določnejši tip junaka, kakršnega je v zametkih najti že v Bahtinovi tipologiji (avto)biografskega junaka, ki jo je razvil na osnovi biografske vrednostne zavesti $v$ tu obravnavanem spisu.

Bahtin razlikuje med družbeno-vsakdanjim in avanturno-heroičnim tipom, pri čemer slednjega zaznamuje hotenje biti slavni junak in ga pri Kovačiču le stežka najdemo; bližji mu je družbeno-vsakdanji tip, ki je osredotočen na socialne in družinske vrednote in v katerem prevladuje opisni moment. Bahtin ugotavlja, da je pri tem tipu pogosto moč razlikovati dve ravni: eno, na kateri je pripovedovalec-junak slabo prilagojen drugim, pomaknjen na notranjo raven in nekako na meji pripovedi, v katero se zdaj vključuje kot biografski junak, zdaj si prizadeva, da bi se ujemal z avtorjem-nosilcem oblike, zdaj se približa subjektu izpovedi kot obračuna s samim seboj, in drugo, ko so delujoče osebe lahko značaji in celo tipi, katerih poteze so podane $\mathrm{v}$ zavesti glavnega junaka-pripovedovalca, dejanskega biografskega junaka, ki je približan avtorju. V tej dvoravenskosti vidi Bahtin tudi začetno razpadanje biografskega sveta, trenutek, ko avtor postaja kritičen, ko njegova pozicija zunajbivanja postaja $\mathrm{v}$ odnosu do drugega pomembna, ko njegovo vrednostno ujemanje s svetom drugih slabi in se zmanjšuje avtoriteta vrednostne pozicije drugega (Bahtin 1999: 174, 180-181).

Te značilnosti družbeno-vsakdanjega junaka so pri Kovačiču radikalizirane, njegov junak ne pozna biografskega sveta $\mathrm{v}$ Bahtinovem smislu, ker v avtorju nima nadrejene zaključujoče zavesti in ni vrednostne pozicije drugega. Drugi, ki se pojavlja tudi v Kovačičevem pisanju, tu nima vloge organizirajočega estestkega principa ali avtoritete kot pri Bahtinu, temveč je na isti ravni kot »jaz«, njemu enakovreden ali se z njim lahko prekriva, kajti Kovačič meni:

[...] mi vsi smo narejeni iz enega velikega kosa in noben jaz ni zato povsem on sam. Samo absorbiramo in organiziramo kaos $\mathrm{v}$ neki določeni ali nedoločeni ekstremni obliki drugače od drugega ... [...] Nihče, ki je drugi, ni povsem drug, ampak je jaz, kakor sem jaz tule, in jaz nisem bil nikoli nekaj docela drugačnega od drugih. (Kovačič 1988: 212)

Zato Kovačič človeka ne vidi toliko v večnem nestrinjanju s svetom, temveč predvsem s samim seboj, saj se stalno ustvarja in uničuje v naključnih zvezah z drugimi in se vsa njegova spoznanja o pomenu in dejanjih oblikujejo »med ljudmi«, ker

${ }^{20}$ Zlasti v knjigah Pet fragmentov (1981) oz. Tri ljubezni (2004) in Vzemljohod (1993). 
so mu čustva, vse vere sveta in prepričanja naložena »od zunaj, na pot sprotnega oblikovanja, skozi njegovo stalno preoblikujočo se formo« (Kovačič 1990: 197).

Drugi pa Kovačiču lahko tudi pomeni možnost za pripovedovanje »objektivne zgodbe« o sebi pred svojim začetkom, in sicer tako, da poda »zgodbo ali legendo življenja«, kot je ta odmevala v njem samem, ko so mu jo pripovedovali drugi (Kovačič 1997: 58). Tu seveda ne gre za tako pripovedovanje drugih, ki je pri Bahtinu pogoj za vrednostno biografsko enotnost, temveč za pripovedovanje, ki omogoča razširitev subjektivnega notranjega pogleda na lastno predzgodovino in na to, kar je zunaj dosega biološkega spomina.

Ker je Kovačič povsem osredotočen na lastno osebo ni čudno, da vidi v sebi tudi prvega naslovljenca svojega pisanja; še več: pripovedovanje samemu sebi, ne drugim, se mu zdi »največji dosežek, ki ga je moč osvojiti«, kajti »nič ni plodovitejšega za bralca, kakor če kot tretja priča prisostvuje doslednemu dialogu avtorja s samim seboj«. Od take literature pa Kovačič zahteva da,

[...] mora biti »popolna« in ne sme biti pisana pod kontrolo nobenega določenega smisla.

[...] Človeka naj bi na novo sestavila v sebi, kakor se človek sestavlja v resnici vsak dan tudi sam na novo, tako, kot je, zmeraj isti in vedno drugačen pred samim seboj; to, kar je sprejel ta trenutek za svoje, bo v naslednjem izpustil iz rok; nič naj ne bo ne duhovno, ne dokončno pripeto nikamor: neprepričljivo ko življenje, odprto, antisinteza vsemu, kaos, skozi katerega se človek giblje bolj v svoji cerebralni, kakor seksualni, socialni ali dednostni sferi. (Kovačič 1997: 187)

Prav s to popolnostjo, ki nastaja iz fragmentov, in z odpovedjo določenemu smislu Kovačič ustvari pogoje, da bralcu ni več pomembno, ali so opisane osebe in dogodki »vzeti« iz realnega sveta oziroma ali prikazano odgovarja resnici, ali je imaginirano, izmišljeno. Bralec se lahko prepusti toku pripovedi tako kot se avtor prepusti procesu pisanja, v katerem se njegov »junak« vedno spet konstituira na novo in se spreminja $z$ vsakim zapisom. V tem smislu obstaja junak samo v jeziku, v toku katerega skuša Kovačič razkriti čim več svojih »jazov« in odtenkov možne resničnosti, ki izvirajo iz neprepričljivosti realnega življenja.

\section{ZAKLJUČKI}

Primerjava med pojmovanjem avtobiografije v zgodnjih delih Mihaila M. Bahtina in avtobiografskem pisanju Lojzeta Kovačiča pokaže, da oba izhajata iz humanistično-etičnih pogledov na ustvarjalnost in da se njuna razmišljanja ujemajo zlasti tedaj, kadar je mogoče govoriti o etičnem dogodku življenja. Oba izhajata tudi iz tega, da med avtorjem, pripovedovalcem in junakom nikoli ne more biti dejanske skladnosti, razlikujeta pa se $\mathrm{v}$ tem, da Bahtin gleda na razmerje avtorja do avtobiografskega junaka na osnovi splošnih pogojev estetske dejavnosti, ki zahtevajo vrednostno in zaključujočo pozicijo drugega, medtem ko Kovačič v svoji literaturi dosledno uveljavlja spoznanje o razbitosti in fragmentarnosti tako življenja kot človeka. Pogoje estetske dejavnosti Bahtin v svojih poznejših teorijah dialoga in polifonije v romanu sicer revidira in se zavzema za estetiko nezaključenosti in življenja, to- 
da (avto)biografija mu še naprej pomeni predvsem obliko objektiviranega življenja, ki ni docela estetsko delo. Zaveda se krize subjekta v obliki krize avtorstva in jo skuša preseči s trdnim položajem zunajbivanja avtorja $\mathrm{v}$ odnosu do junaka, medtem ko je kriza subjekta in nenazadnje tudi jezika integralni del Kovačičeve ustvarjalnosti in njegovih pogledov na samega sebe.

Pri obeh avtorjih je mogoče ugotoviti kritično stališče do konvencionalnih oblik avtobiografije, saj je Bahtin ne obravnava celostno, temveč v sklopu svojega zanimanja za razmerje med avtorjem in junakom zlasti v romanu, Kovačič pa ji postavalja nasproti svojo avtobiografsko pisavo. Vzorci tradicionalne avtobiografije se izkažejo kot problematični tako v sklopu Bahtinove estetike zunajbivanja in zaključenosti in njegovih teorijah dialoga in polifonije kot tudi v Kovačičevem razumevanju fragmentarnosti življenja in literature. V tem lahko vidimo potrditev težnje, da se oblike konvencionalne avtobiografije v literaturi 20. stoletja razvijajo predvsem pri avtorjih, ki sledijo objektivnim, praktičnim ali znanstveno-zgodovinskim smotrom, medtem ko je zavest o krizi subjekta in jezika, če samo pomislimo na dela S. Freuda in F. Nietzscheja, nujno privede do novih oblik avtobiografije in avtobiografskega pisanja.

\section{Literatura}

Bahtin 1979:

Bahtin 1982:

Bahtin 1985:

Bahtin 1999:

Dilthey 1993:

Dilthey 2002:

Dolgan 2004:

Juvan 1997:

Komelj-Snoj 1997:

Koron 1991:

Kovačič 1981: Kovačič 1985:

Kovačič 1988:

Kovačič 1990:

Kovačič 1993:

Kovačič 1997:

Kovačič 1999:
Michail M. Bachtin, Ėstetika slovesnogo tvorčestva, sostavitel' S. G. Bočarov, primečanija S. S. Averinceva i S. G. Bočarova, Moskva Mihail M. Bachtin, Teorija romana, Ljubljana

Michail M. Bachtin, Probleme der Poetik Dostoevkijs, Frankfurt a. M. Mihail M. Bachtin, Estetika in humanistične vede, Ljubljana Wilhelm Dilthey, Der Aufbau der geschichtlichen Welt in den Geisteswissenschaften, 4. zv., Frankfurt a. M.

Wilhelm Dilthey, Zgradba zgodovinskega sveta v duhoslovnih znanostih (= Zbirka Phainomena 17), Ljubljana

Marjan Dolgan, Véliki tekst o demistifikaciji „Velikega teksta“ ali Prišleki Lojzeta Kovačiča, v: isti: Slovenska književnost tako ali drugače, Ljubljana, 141-165

Marko Juvan, Predgovor, v: Bahtin in humanistične vede - Bakhtin and the Humanities. Zbornik prispevkov $\mathrm{z}$ mednarodnega simpozija $\mathrm{v}$ Ljubljani, 19. -21. oktobra 1995, Ljubljana, 5-14

Mateja Komelj-Snoj, Komaj se rodimo, že pripadamo. Intervju, v: Kovačič 1997, 189-225

Alenka Koron, Prispevki za žanrsko skico Kovačičevega pisateljskega opusa. Prispevek s kolokvija o slovenskem romanu v Jeruzalemu, 22. 6. 1991, Literatura III/13, 62-74

Lojze Kovačič, Pet fragmentov, Ljubljana

Lojze Kovačič, Prisleki. Pripoved, 3. del, Ljubljana

Lojze Kovačič, Prah. Dnevnik, zapažanja, reminiscence, Ljubljana

Lojze Kovačič, Kristalni čas, Ljubljana

Lojze Kovačič, Vzemljohod, Ljubljana

Lojze Kovačič, Delavnica. Sola pisanja (= Znamenja 129), Maribor [1974]

Lojze Kovačič, Literatura ali življenje. Eseji, članki, dnevniki, Ljubljana 
Leben 2007:

Misch 1949:

Zor-Simoniti 2000:
Andreas Leben, Probleme der Autobiographieforschung im slowenischen Kontext, Wiener Slavistisches Jahrbuch 53, 91-107

Georg Misch, Geschichte der Autobiographie, 1. zv., Bern [1907]

Alenka Zor-Simoniti, Življenje je okno, literatura je zrcalo. Pogovor z Lojzetom Kovačičem, Ampak I/1, 50-52

\section{Res üm e e}

Während Bachtin in seiner frühen Abhandlung Avtor i geroj v éstetičeskoj dejatel'nosti davon ausgeht, dass der Autor in Bezug auf sich selbst ein anderer werden muss, um das Ganze des Lebens darstellen und ästhetisch tätig werden zu können, stützt sich Kovačič in seinem Werk ganz auf das Fragment als Ausdruck einer Welt, die sich nicht mehr abschließen lässt, was auch die äußere Form seiner Literatur prägt, der er stofflich sein eigenes Leben zugrunde legt. Da Kovačič zwischen biologischer Existenz, persönlichen Reflexionen und dem Akt des Schreibens unterscheidet, von sich selbst als jemand Anderem spricht, jemand, der sich ständig verändert, der ihm unzugänglich (geworden) ist, liegt auch bei ihm keine völlige Identität von Autor, Erzähler und Held bzw. literarischer Figur vor. Bachtin bindet die ästhetische Tätigkeit zwingend an das Außensein (russ. vnenachodimost') des Autors in Bezug auf den Helden und sieht im nicht wertbestimmten Leben nur die Möglichkeit ethischer Handlungen. Die größtmögliche Annäherung von Autor und Held schreibt Bachtin nun gerade der Autobiographie zu, allerdings um den Preis des Ganzen und zu Lasten der ästhetischen Tätigkeit. Das für Kovačič so wichtige biographische Fragment, das Bekenntnis, jeder reine Bezug auf sich selbst, bringt Bachtin zufolge keine einheitliche Biographie hervor. Für ihn bildet eine Lebensgeschichte den Stoff, den es durch die Position des vom oder von den anderen wertmäßig bestimmten Außenseins ästhetisch zu formen gilt, wobei er einräumt, dass auch der Autor einer Autobiographie ein vollkommener Künstler werden könne, wenn er dem Leben des Helden mit Skepsis begegne, wenn zwischen Held und Autor eine prinzipielle Grenze trete. Kovačič misst den höchsten Wert wiederum der Unabgeschlossenheit, Unerschließbarkeit und ethischen Dimension des realen Lebens zu, vor dem sich die Literatur niemals schämen dürfe. Darin besteht auch der wesentliche Unterschied in der Beurteilung des Zusammenhangs von Leben, Autor und Held bei Bachtin und Kovačič, die beide von einem humanistischen Standpunkt ausgehen und deren Betrachtungen hinsichtlich der Ästhetik des Lebens einander durchaus nahe stehen, was insbesondere Bachtins spätere Theorien des Dialogs und der Polyphonie verdeutlichen. Gemeinsam ist ihnen aber auch, dass sie der Autobiographie, vor allem in ihrer konventionellen Form, nur bedingt ästhetischen Wert beimessen.

Andreas Leben

Institut für Slawistik der Universität Wien

Universitätscampus AAKH, Hof 3

Spitalgasse 2, 1090 Wien, Österreich

andreas.leben@univie.ac.at 